УДК

Кривова С. Г. ${ }^{1}$, Зубаньов О..$^{2}$

${ }^{1}$ Національний технічний університет України «Київський політехнічний інститут імені Ігоря Сікорського». Україна, м. Київ

${ }^{2} \mathrm{AT}$ «Український науково-дослідний інститут авіаційної технології». Україна, м. Київ

\title{
ПІДХОДИ ЩОДО КОРЕКЦІЇ РАННІХ СТАДІЙ ПРОЕКТІВ НАУКОЄМНОГО МАШИНОБУДУВАННЯ
}

Представлений аналіз підходів до формування цілей проекту на ранніх стадіях проектів наукоємного машинобудування.

Показана можливість неефективності проекту внаслідок безальтернативного формування цілей у випадку недостатньої компетенції Замовника проекту та недостатньої формалізації процедур прийняття рішень на ранніх стадіях проектів наукоємного машинобудування.

Запропоновані заходи щодо формалізації процедур прийняття рімень на ранніх стадіях проектів наукоємного машинобудування. [dx.doi.org/10.29010/89.7]

Ключові слова: проектний менеджмент; наукоємне машинобудування; ранні стадії проекту; RFI; RFP; життєвий иикл наукоємного проекту; техногеном проекту.

\section{Вступ}

Сучасні проекти наукоємного машинобудування, до яких відноситься і авіабудування, характеризуються високою вартістю та значною тривалістю (рис. 1). Загальновідомо, що вірогідність подій, пов'язаних з ризиками, найбільш значна на ранніх стадіях життєвого циклу проекту, що обумовлено значною невизначеністю та багатоваріантністю потенційних рішень [1].

В той же час, досвід участі у реалізації наукоємних проектів свідчить, що саме ранні стадії створення наукоємного продукту слабо формалізовані, у типових методичних рекомендаціях найважли-

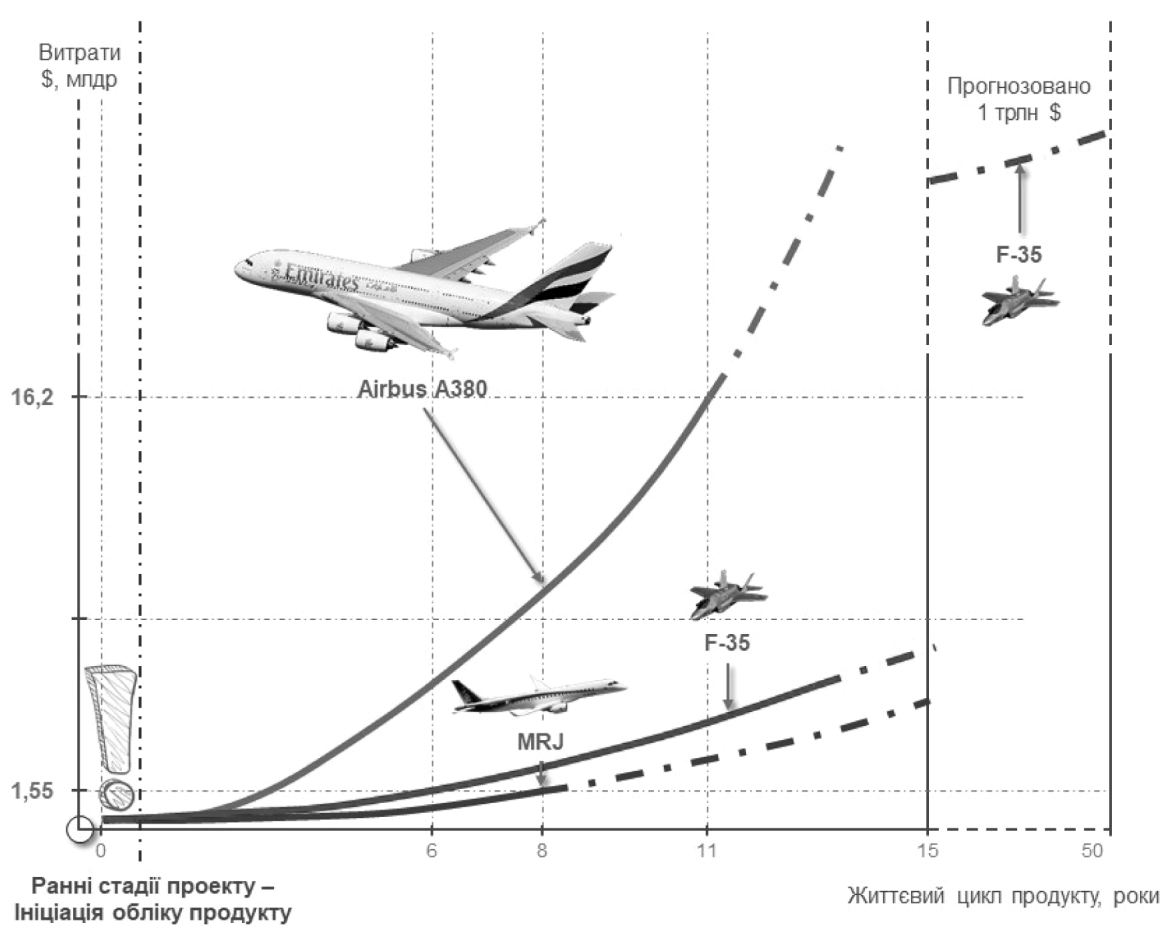

Рис. 1. Вартість відомих авіабудівних проектів [4]

(C) Кривова С. Г., Зубаньов О. С., 2019 
віші процеси вироблення і схвалення рішень на ранніх стадіях життєвого циклу проекту охоплені узагальнено 3 швидким переходом до процесів планування.

\section{Постановка задачі}

У класичній системній інженерії, що використовується у тому числі у складних проектах наукоємного машинобудування, життєвий цикл системи розпочинається зі стадії розроблення Концепції, що повинна включати: а) аналіз проблеми на предмет їі дійсної наявності та потреби у її вирішенні та оцінці реальності вирішення проблеми; б) дослідження альтернативних варіантів вирішення проблеми; в) визначення оптимальної концепції на основі порівняння альтернативних варіантів [2]. В якості альтернативних досліджуються варіанти конструкцій виробу, рівня локалізації виробництва, промислової кооперації, фінансування проекту тощо. Враховуючи унікальність проектів наукоємного машинобудування, множинність альтернативних варіантів основним інструментом дослідження, оцінки та вибору оптимальних рішень виступає метод експертних оцінок, що потребує залучення висококваліфікованих експертів відповідного профілю та виділення додаткових ресурсів (часу та коштів). Ситуація ускладняється у випадку ініціації проекту Замовником проекту (стороною, що зацікавлена в реалізації проекту) з недостатнім рівнем компетенцій [3].

Таким чином, актуальним вважається розроблення пропозицій щодо підвищення рівня формалізації процедур прийняття рішень на ранніх стадіях проектів наукоємного машинобудування.

\section{Підходи до вирішення задачі}

У випадку ініціації проекту створення виробництва літака Замовник проекту за традиційною методологією самостійно формує запит інформації (Request for Information, далі - RFI), щодо потенційних можливостей задоволення потреб Замовника проекту та потенційних умов можливих претендентів-виконавців проекту.
Після виявлення потенційних компетентних (за оцінкою Замовника проекту) претендентів, Замовник проекту формує запит пропозиції (Request for Proposal, далі - RFP), що призначений для порівняння потенційних претендентів на виконання послуги і оцінювання їх придатності для участі в подальших тендерних процесах (рис. 2).

Практичний досвід свідчить, що Замовник Ідеї часто безальтернативно формулює цілі проекту. Наприклад, жорстко конкретизується тип майбутнього продукту - літак такого-то типу та класу; чітко визначається локалізація виробництва продукту - за географічним принципом; фіксується тип виробництва продукту - мінімально можливий склад усіх видів виробництва кінцевого складання; жорстко прописуються екологічні характе-

\begin{tabular}{|c|c|}
\hline RFI - Запит інформації & RFP - Запит пропозиції \\
\hline $\begin{array}{l}\text { 1. Background - Резюме Проекту } \\
\text { - Найменування Проекту. } \\
\text { - Задум Проекту та облік очікуваних } \\
\text { результатів Проекту. } \\
\text { - Заява щодо цілей Проекту. } \\
\text { - оповні задачі Проекту. } \\
\text { - Зацікавлені сторони Проекту. }\end{array}$ & $\begin{array}{l}\text { 1. Background - Резюме Проекту } \\
\text { - Найменування та очікувані результати } \\
\text { Проекту. } \\
\text { - Зацікавлені сторони Проекту. } \\
\text { - Постановка задачі і ціпі Послуги.. } \\
\text { - оловні вимоги до Послуги. } \\
\text { - ритерії якості Послуги. } \\
\text { Критерії вибору виконавця Послуги. }\end{array}$ \\
\hline $\begin{array}{l}\text { 2. Timeline - Графрік Послуги } \\
\text { - Пажані терміни реалізації. } \\
\text { План-графік робіт Послуги. } \\
\text { 3. Response Guidelines - } \\
\text { Рекомендації для відповіді } \\
\text { - Формулювання змісту Послуги. } \\
\text { - Кажана тематика відповідей в RF. } \\
\text { Ключові питання, на які бажано надати } \\
\text { можливі відповіді. } \\
\text { Заохочення розширення інформації у } \\
\text { відповідях за Послугою. }\end{array}$ & $\begin{array}{l}\text { 2. Scope of Work - 3міст Послуги } \\
\text { - Очікуваний зміст Поспуги: аналіз } \\
\text { потенциалу ринку і оцінка перспектив } \\
\text { результатів Проекту; розробка і } \\
\text { реалізація змісту Проекту; модель } \\
\text { фінансування; модель оргструктури і } \\
\text { управління. } \\
\text { - Методика надання Послуги. } \\
\text { - Обгрунтування альтернативного } \\
\text { підходу. }\end{array}$ \\
\hline 4. Document Requirements - & $\begin{array}{l}\text { 3. Timeline - Графік Послуги } \\
\text { • Директивні терміни і план-графік робіт } \\
\text { Послуги. }\end{array}$ \\
\hline $\begin{array}{l}\text { Побажання до інформації- } \\
\text { відповіді } \\
\text { - узагальнені відповіді на ключові } \\
\text { питання. } \\
\text { - Практичний досвід успішної діяльності у } \\
\text { предметній галузі. } \\
\text { - адровий потенціал дпя робіт за }\end{array}$ & $\begin{array}{l}\text { 4. Document Requirements - } \\
\text { Вимоги до документу } \\
\text { - Мінімальні вимоги до змісту пропозиції } \\
\text { до кожного розділу Послуги. } \\
\text { - Вимоги до офрормлення пропозиції. }\end{array}$ \\
\hline $\begin{array}{l}\text { Послугою. } \\
\text { - Бажана тривалість робіт Послуги. } \\
\text { - Орієнтовна вартість роботи. } \\
\text { - Додаткова інфрормація. }\end{array}$ & $\begin{array}{l}\text { 5. Ownership \& Knowledge Transfer } \\
\text { - Права, передача знань } \\
\text { - Права та область застосування RFP. } \\
\text { - Конфіденційність, розповсюдження. }\end{array}$ \\
\hline $\begin{array}{l}\text { 5. Evaluation Criteria - Критерії } \\
\text { Оцінки } \\
\text { Критерії оцінки інформації у відповідь на } \\
\text { RF. } \\
\text { - Критерії відбору тих, хто отримає RFP. }\end{array}$ & $\begin{array}{l}\text { 6. Evaluation Criteria - Критерії } \\
\text { Оцінки } \\
\text { 7. Other Terms and Conditions - } \\
\text { Інші умови }\end{array}$ \\
\hline $\begin{array}{l}\text { 6. Confidentiality - } \\
\text { Конфіденційність } \\
\text { - Права та область застосування RF. } \\
\text { - Розповсюдження, копіювання тощо. }\end{array}$ & \\
\hline
\end{tabular}

Рис. 2. Схема RFI та RFP для літакобудівельного проекту (за досвідом АТ УкрНДІАТ) 
ристики майбутнього продукту. Як наслідок, такі безальтернативні цілі часто конкретно фіксуються в RFP і стають початковими даними для майбутнього процесу ухвалення рішень на ранніх стадіях проекту, в т.ч. розробці техніко-економічного обгрунтування (TEO) проекту і бізнес-плану проекту. У результаті можуть бути не враховані важливі альтернативні варіанти рішень, що в майбутньому може зробити проект неефективним.

\section{Пропозиції щодо підвищення рівня формалізації процедур прийняття рішень на ранніх стадіях проектів наукоємного машинобудування}

Корекція ранніх стадій ініціації проектів наукоємного машинобудування передбачує, що Замовник проекту повинен формулювати цілі проекту 3 урахуванням можливих альтернативних варіантів щодо типу продукту, локалізації виробництва, рівня кооперації тощо та оцінки корисності альтернатив у майбутньому (1):

$$
\mathrm{P}(\mathrm{A}) \leftrightarrow \mathrm{P}(\mathrm{B}) \leftrightarrow \mathrm{P}(\mathrm{K}),
$$

де $\mathrm{P}(\mathrm{A}), \mathrm{P}(\mathrm{B}), \mathrm{P}(\mathrm{K})$ - альтернативи варіантів рішень.

Функція корисності альтернатив може бути визначена на основі добре відомих та апробованих методів MAUT (Multi-Attribute Utility Theory), AHP (Analytic Hierarchy Process) [5] та інших подібних (табл. 1).
Вже на ранніх стадіях проекту може бути отримана шкала переваг показників якості альтернатив (2):

$$
S_{j}=\sum_{i=1}^{N} W_{i} \cdot V_{j i}
$$

де $S_{j}-$ показник якості; $j$ - альтернатива; $W_{i}-$ «вага» $i$-го критерія; $V_{j i}-$ важливість $j$-ї альтернативи за $i$-м критерієм.

Отримані результати можуть бути використані при оформленні RfI і враховані при підготовці RfP. Таким чином, зменшується можливість того, що при підготовці ТЕО і Бізнес-моделі будуть втрачені можливо перспективні і дуже важливі варіанти майбутнього проекту.

Корекція ранніх стадій ініціації проектів наукоємного машинобудування передбачує також залучення консультантів-експертів для формулювання коректних цілей майбутнього проекту [3].

3 урахуванням запропонованих корекцій ранні етапи проекту можуть бути названі - «Техногеном Проекту». Від того, наскільки ретельно буде опрацьований «Техногеном Проекту» багато в чому залежатиме й майбутня успішність проекту. Збільшення витрат на це опрацювання багаторазово окупиться: або під час майбутньої реалізації проекту, або дозволить уникнути витрат при визнанні проекту неефективним на ранніх стадіях (рис. 3).

\begin{tabular}{|c|c|c|c|c|c|}
\hline Альтернатива & A & B & $\mathbf{K}$ & \multicolumn{2}{|c|}{$\begin{array}{c}\text { Розрахункові параметри альтернатив } \\
\text { за критеріями }\end{array}$} \\
\hline \multicolumn{6}{|c|}{ За критерієм $\mathrm{C}_{1}$} \\
\hline A & $\checkmark$ & $\checkmark$ & $\checkmark$ & $\mathrm{N}_{1.1}$ & $\mathrm{~N}_{1.2}$ \\
\hline B & $\checkmark$ & $\checkmark$ & $\checkmark$ & $\mathrm{N}_{1.3}$ & $\mathrm{~N}_{1.4}$ \\
\hline K & $\checkmark$ & $\checkmark$ & $\checkmark$ & $\mathrm{N}_{1.5}$ & $\mathrm{~N}_{1.6}$ \\
\hline \multicolumn{6}{|c|}{ За критерієм $\mathrm{C}_{2}$} \\
\hline $\mathrm{A}$ & $\checkmark$ & $\checkmark$ & $\checkmark$ & $\mathrm{N}_{2.1}$ & $\mathrm{~N}_{2.2}$ \\
\hline $\mathrm{B}$ & $\checkmark$ & $\checkmark$ & $\checkmark$ & $\mathrm{N}_{2.3}$ & $\mathrm{~N}_{2.4}$ \\
\hline $\mathrm{K}$ & $\checkmark$ & $\checkmark$ & $\checkmark$ & $\mathrm{N}_{2.5}$ & $\mathrm{~N}_{2.6}$ \\
\hline \multicolumn{6}{|c|}{ За критерієм $\mathrm{C}_{\mathrm{n}}$} \\
\hline A & $\checkmark$ & $\checkmark$ & $\checkmark$ & $\mathrm{N}_{\mathrm{n} .1}$ & $\mathrm{~N}_{\mathrm{n} .2}$ \\
\hline B & $\checkmark$ & $\checkmark$ & $\checkmark$ & $\mathrm{N}_{\mathrm{n} .3}$ & $\mathrm{~N}_{\mathrm{n} .4}$ \\
\hline K & $\checkmark$ & $\checkmark$ & $\checkmark$ & $\mathrm{N}_{\mathrm{n} .5}$ & $\mathrm{~N}_{\mathrm{n} .6}$ \\
\hline
\end{tabular}

Матриця оцінки відносної важливості альтернатив за критеріями $\left(\mathrm{C}_{1}, \mathrm{C}_{2}, \ldots \mathrm{C}_{\mathrm{n}}\right)$ 


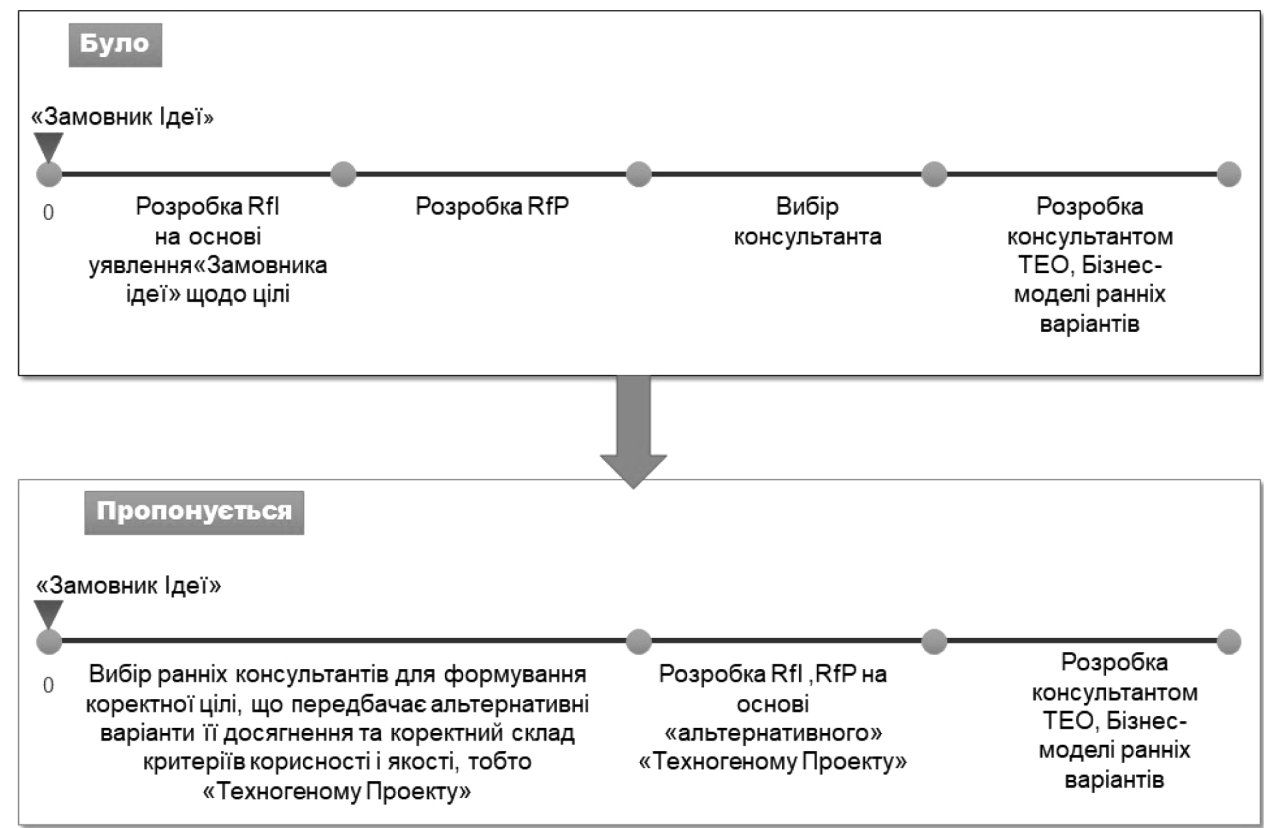

Рис. 3. Схема корекції ранніх стадій проектів наукоємного машинобудування

\section{Висновки}

1. Основною причиною необхідності корекції ранніх стадій проектів наукоємного машинобудування виявляється безальтернативне формулювання цілей проекту Замовником.

2. Корекція ранніх стадій проектів наукоємного машинобудування передбачатиме вибір консультантів-експертів для формування коректної цілі 3 урахуванням можливих альтернативних варіантів - «Техногеному Проекту».

3. Роботи $з$ вдосконалення процесу прийняття рішень на ранніх стадіях проектів наукоємного машинобудування, а саме уточнення і розроблення методів і інструментів людино-машинних процедур в ході аналізу і схвалені рішень, будуть продовжені.

\section{Абревіатури}

RFI - Request for Information, запит інформації RFP - Request for Proposal, запит пропозиції

MAUT - Multi-Attribute Utility Theory

AHP - Analytic Hierarchy Process

TEO - Техніко-економічне обгрунтування

\section{Література}

[1] Клиффорд Ф. Грей, Эрик У. Ларсон. Управление проектами: Практическое руководство [Текст] / Пер. с англ. - М.: Издательство «Дело и Сервис», 2003. - 528 с.: ил. - Пер. изд.: Project management / C. F. Gray, E. W Larson. - ISBN 0-07-365812-X. ISBN 5-8018-0152-9

[2] ГОСТ Р ИСО/МЭК 15288-2005 Информационная технология. Системная инженерия. Процессы жизненного цикла систем [Национальный стандарт Российской Федерации]. - М.: Стандартинформ, 2006. - 57 с.: 28,5 см. - Библиогр: с. 53. - 385 экз.

[3] Krivova, S. G. Peculiarities of initial data formation for decision making at early stages of life cycle of scienceintensive projects [Текст] / S. G. Krivova, A. Ye. Zubanjov// Технологические системы - 2019, № 2, Киев, с. 19-24.

[4] https://expert.ru/ratings/stoimost-razrabotki-novyihsamoletov-i-remotorizatsii-suschestvuyuschih-modelej/

[5] Ларичев О. И. Теория и методы принятия решений, а также хроника событий в волшебных странах. М.: Логос, 2000. - 296 с. 
Krivova S. G. ${ }^{1}$, Zubanjov A. Ye. ${ }^{2}$

${ }^{1}$ National Technical University of Ukraine “Igor Sikorsky Kiev Polytechnic Institute”. Ukraine, Kiev

${ }^{2}$ Ukrainian Research Institute of Aviation Technology, JSC. Ukraine, Kiev

\section{APPROACHES TO EARLY STAGES CORRECTION OF SCIENCE-INTENSIVE MACHINE BUILDING}

The analysis of modern approaches to the formation of the project goals at the early stages of scienceintensive machine building projects is presented.

The possibility of making inefficiency of the project as a result of non-alternative formation of goals in case of insufficient competence of the Customer of the project and insufficient formalization of decision-making procedures at the early stages of science-intensive machine building projects is shown.

Measures for decision-making procedures formalization at the early stages of science-intensive machine building projects are proposed. [dx.doi.org/10.29010/89.7]

Keywords: project management; science-intensive machine building; early stages of project; RFI; RFP; life cycle of science-intensive project; project technogenome.

\section{References}

[1] Project Management: The Managerial Process by Clifford E. Gray and Erik W. Larsen - Irwin/McGraw Hill Series, Operations and Decision Sciences, 1999. - 496 p. - ISBN-13: 978-0-07-365812-4, ISBN: 0-07-365812-X.

[2] ISO/IEC/IEEE 15288:2015 Systems and software engineering - Systems life cycle processes.

[3] Krivova, S. G. Peculiarities of initial data formation for decision making at early stages of life cycle of science-intensive projects [Текст] / S. G. Krivova, A. Ye. Zubanjov// Technological Systems. - 2019, № 2, - Kiev, p. 19-24.

[4] https://expert.ru/ratings/stoimost-razrabotki-novyih-samoletov-i-remotorizatsii-suschestvuyuschih-modelej/

[5] Larichev O. I. Theory and methods of decision-making, as well as a chronicle of events in magic countries. - M.: Logos, 2000. $-296 \mathrm{p}$ 